\title{
Evaluation of the Effect of Clinical Scenario-Based Educational Workshop and Reflection on the Knowledge and Attitude of Head Nurses and Clinical Supervisors toward in the Brain Death and Organ Donation
}

\author{
Mostafa Bijani ${ }^{1}$, Saeed Hamidizadeh ${ }^{2}$, Khatereh Rostami ${ }^{3}$, Aboutaleb Haghshenas ${ }^{4}$, Fatemeh Mohammadi ${ }^{5}$, \\ Afsaneh Ghasemi ${ }^{6}$, Razieh Assodeh ${ }^{7^{*}}$
}

\author{
${ }^{1}$ Assistant Professor, Department of Medical Surgical Nursing, Fasa University of Medical Sciences, Fasa, IRAN \\ ${ }^{2} \mathrm{Ph}$.D. candidate in nursing, Student Research Committee, Department of Nursing and Midwifery, Shiraz University of Medical Sciences, Shiraz, IRAN \\ ${ }^{3}$ Community Based Psychiatric Care Research Center, Shiraz University of Medical Sciences, Shiraz, IRAN \\ ${ }^{4}$ M.sc, MSN. Department of Nursing, School of Nursing and Midwifery, Bam University of Medical Sciences, Bam, IRAN \\ ${ }^{5}$ Chronic Diseases (Home Care) Research Center, and Pediatric Nursing Department, Hamadan University Of Medical Sciences, Hamadan, IRAN \\ ${ }^{6}$ Assistant Professor of Health Education, Department of public Health, Fasa University of Medical Sciences, Fasa, IRAN \\ ${ }^{7}$ Department of Medical Surgical Nursing, Fasa University of Medical Sciences, Fasa, IRAN \\ *Corresponding Author: assodeh.rz@yahoo.com
}

Citation: Bijani M, Hamidizadeh S, Rostami K, Haghshenas A, Mohammadi F, Ghasemi A, Assodeh R. Evaluation of the Effect of Clinical ScenarioBased Educational Workshop and Reflection on the Knowledge and Attitude of Head Nurses and Clinical Supervisors toward in the Brain Death and Organ Donation. Electron J Gen Med. 2020;17(5):em233. https://doi.org/10.29333/ejgm/7903

ARTICLE INFO

Received: 21 Sep. 2019

Accepted: 28 Jan. 2020

\section{ABSTRACT}

Background: Participation in the organ donation process is a part of the expected activities in the nursing profession and nurses play a major role in this regard. Providing correct information by nurses increases the number of organ donors and it requires knowledge and positive attitude towards organ donation. The present study was conducted with the aim of evaluating the effect of clinical scenario-based educational workshop and re-thinking on the knowledge and attitude of head nurses and clinical supervisors working in Valiasr Hospital of Fasa in southwestern of Iran in 2019.

Materials and Methods: This was a pre-test and post-test type of quasi-experimental study. A total of 50 head nurses and clinical supervisors were randomly divided into intervention and control groups (each group contained 25 subjects). Reflective thinking and clinical scenario-based educational program was implemented for the intervention group in four sessions, 2 hours per session. Then, the mean score of knowledge and attitude in both groups was assessed before, immediately and one month after intervention. Data were analyzed using independent t-test، Chi-square and ANOVA through SPSS, version 22, software.

Results: The attitude $(P=0.47)$ and knowledge $(P=0.78)$ of head nurses and clinical supervisors in two groups did not differ significantly before training. Intervention group had a significant improvement in attitude and knowledge after training compared to the control group. $(\mathrm{P}<0.05)$

Conclusion: Clinical scenario-based education and Reflective thinking was effective in enhancing the knowledge and attitude of nurses towards brain death and organ donation. Thus, it is recommended that nursing managers can consider necessary measures and plans in this regard.

Keywords: organ donation, knowledge, attitude, nurse, education

\section{INTRODUCTION}

Organ transplantation as one of the major medical developments and progresses in treatment of patients with dysfunction in organs plays a vital role in improving the quality of life and increasing the life expectancy of patients (1). The role of nurses has grown with increasing the number of organ donations in the world and in Iran, so that attention of nursing care has shifted from nursing care to the donation process and accordingly the role of nurses has also changed (2). Nurses play a key role in identifying organs, effectively following the needs of brain death patients, educating people and nursing the organ donors (3). Participation in the organ donation process is a part of the expected activities in the nursing profession and nurses play a key role in this regard (4). Nurses can play a major role in identifying the organ donors and obtaining their family`s consent for organ donation (5). Having a positive knowledge and attitude toward organ donation in nurses encourages the death brain patient's families to announce their consent in organ donation (6). Nurses can encourage families of brain death patients for organ donation by providing appropriate information to them. Providing correct information about donation requires having a positive attitude and knowledge about it (7-8). Studies conducted in Iran suggested that nurses' knowledge and attitude toward organ 
donation is at the low level. The researchers of the studies have stated that holding educational programs can play a major role in increasing the level of knowledge and improving the performance of nurses in organ donation (9-10). The results of studies conducted in other countries also suggested that nurses' knowledge in the area of brain death and organ donation is at low level. In this regard, the results of studies conducted by Naçar et al. (2015) in Turkey, Khalid et al. (2019) in Pakistan, Poreddi et al. (2016) in India and Huern et al. (2016) in Malaysia showed that nurses' knowledge of organ donation was at low level and educational interventions were needed in this area (11-14). Nursing staff can play an important role in the organ donation process and the most studies conducted in Iran on nurses' knowledge and attitudes about brain death and organ donation are descriptive and limited interventional studies have been conducted in this area, and these interventional studies have used only lecture form of education and less modern educational method of clinical scenariobased method leading to active and deep learning has been used (15-17). Hence, the present study was conducted to evaluate the effect of clinical scenario-based educational workshop and re-thinking on the knowledge and attitude of head nurses and clinical supervisors in the area of organ donation in Fasa Hospital in southwestern of Iran in 2019 (18, 19).

\section{MATERIALS AND METHODS}

This study was pre-test and post-test type of a quasiexperimental study conducted at Fasa University of Medical Sciences Hospital in southwestern of Iran since March 2018 to June 2019. The research sample included all clinical head nurses and supervisors. To select the research samples, a list of head nurses and clinical supervisors was first prepared. A total of 50 subjects were randomly assigned into two groups of intervention and control (each group contained 25 subjects). The research inclusion criteria included having a bachelor or higher level of education, lack of participation in brain death related and organ donation courses in the last 6 months. Exclusion criteria of research also included unwillingness to participate in the study and absence in more than two sessions and lack of cooperation at the educational sessions. The researcher provided the necessary explanations on the objectives of the study and the implementation of the workshops after obtaining the permission from the research unit and introducing himself to the participants. Educational workshop sessions were held for test group by providing reflective thinking and clinical scenarios in 4 sessions of 2 hours for one month at the conference hall of the hospital (20). The control group did not receive any educational interventions. The content of the educational program was approved by the professors of the nursing department and professors in the field of organ transplantation as well as the head of organ transplantation department at Fasa University of Medical Sciences. Before holding the educational workshop, the knowledge and attitude questionnaires were completed by the subjects of intervention and control groups. Moreover, immediately and one month after the completion of the educational workshop, the questionnaires were completed by the intervention and control group. To collect data, knowledge and attitude questionnaire in the area of organ donation was used $(21,22)$. The knowledge questionnaire includes 11 questions scored as true (score 2), false (score 1 ) and I do not know (score zero). The lowest score is zero and the highest score is 22. The attitude questionnaire also included 18 questions, scored from I strongly agree (score 4), I agree (score 3), I disagree (score 2), and I strongly disagree (score 1). The lowest score is 18 and the highest score is 72 . Content validity and the reliability of the knowledge and attitude questionnaire have been confirmed by Valiee et al in 2019 (15). In this study, the content validity of the questionnaires was confirmed by 15 nursing professors of Fasa University of Medical Sciences. To confirm the reliability of the knowledge and attitude questionnaire, test-retest method was used. For this purpose, the questionnaire was completed by 50 head nurses and clinical supervisors. They also re-completed the questionnaire after two weeks. The Cronbach's alpha coefficient was obtained 0.89 for the knowledge questionnaire and 0.81 for the attitude questionnaire, indicating desirable level of reliability. Analysis of the data through descriptive and inferential statistical methods was performed using SPSS, version 23, software. To examine the normal distribution of data, the Kolmogorov-Smirnov test was used. Repeated measures of analysis of variance was also used to compare the mean of knowledge and attitude before, immediately and one month after two group and significant level was considered $p<0.05$.

\section{RESULTS}

In this study, 30 (60\%) of the participants were female and $20(40 \%)$ were male; $45(90 \%)$ had a bachelor and $5(10 \%)$ had a master degree. The mean age of participants was $35 \pm 8.12$ and the mean of employment history was $12 \pm 8.32$ years. Before the intervention, only $5(10 \%)$ of the nurses and clinical supervisors in the test group had an organ donation card. After the intervention, 24 (48\%) received the donor card. There was no significant relationship between the employment history and level of education and gender and knowledge and attitude of head nurses and clinical supervisors $(p=0.48)$. There was a significant relationship between attitude and knowledge, so that with increasing the knowledge level, the attitude also increased $(r=0.014)$. The mean score of knowledge and attitude before the educational workshop in two intervention and control groups was not significantly different $(P=0.27)$. Immediately and one month after the training workshop, the mean score of knowledge and attitude in intervention group showed a statistically significant $(\mathrm{P}<0.05)$ (Table 1$)$.

The mean score of attitude before the educational workshop was not significant in both test and control groups ( $p$ $=0.47$ ). Immediately and one month after the educational workshop, the mean scores of attitude showed a significant different in the test and control groups $(\mathrm{P}<0.001)$ (Table 2).

\section{DISCUSSION}

The results of this study, which was conducted to evaluate the effect of clinical scenario-based education on knowledge and attitude of head nurses and clinical supervisors on brain death and organ donation, showed that the level of knowledge and attitude of the test group after the implementation of the educational program increased significantly. The results of the research conducted by Azmandian et al. (2012) on the effect of educational program on knowledge and attitude of nurses in the ICU department of Kerman hospital also showed that the 
Table 1. Comparison of the mean scores of knowledge nurses in the area of organ donation in the intervention and control groups in three stages of before, immediately and one month after the intervention

\begin{tabular}{cccc}
\hline Group & Before the intervention & $\begin{array}{c}\text { Immediately after the } \\
\text { intervention }\end{array}$ & $\begin{array}{c}\text { One month after the } \\
\text { intervention }\end{array}$ \\
\hline intervention & $10.38 \pm 2.39$ & $19.27 \pm 2.63$ & $17.43 \pm 2.39$ \\
\hline control & $10.48 \pm 2.43$ & $12.47 \pm 2.54$ & $12.78 \pm 2.63$ \\
\hline${ }^{\star \star} p$-value & 0.78 & 0.001 & 0.02 \\
\hline${ }^{*}$ rep-value & .034 \\
\hline
\end{tabular}

*repeated measure

${ }^{\star \star}$ T test

Table 2. Comparison of the attitude score of nurses in the area of organ donation in the test and control groups in the three stages of before, immediately and one month after the intervention

\begin{tabular}{cccc}
\hline Group & Before the intervention & $\begin{array}{c}\text { Immediately after the } \\
\text { intervention }\end{array}$ & $\begin{array}{c}\text { One month after the } \\
\text { intervention }\end{array}$ \\
\hline Test & $13.08 \pm 29.17$ & $10.36 \pm 58.27$ & $13.74 \pm 55.46$ \\
\hline Control & $12.49 \pm 27.36$ & $7.31 \pm 29.17$ & $7.58 \pm 29.39$ \\
\hline${ }^{\star \star}$ p-value & 0.47 & $<.001$ & .001 \\
\hline
\end{tabular}

${ }^{*}$ repeated measure

$\star \star T$ test

mean score of attitude and knowledge in the test group increased after the implementation of the educational program and a significant relationship was found between the attitude and knowledge (23-26). The results of this study were consistent with those of the present study (27). The results of the study conducted by Lin et al. (2014) also showed that the implementation of the educational program led to an increase in the knowledge and attitude of the nurses in the area of organ donation $(28,29)$. Moreover, the nurses' attitude increased with increasing the level of knowledge (30-34). The result of this study was consistent with that of the present study (35-37)). The results of the study conducted by Steenaart (2019) also showed that the use of new educational methods can increase the knowledge and attitude of nurses in the area of organ donation, which was consistent with the results of this study (38-42). The results of the studies conducted by Srinivasula et al. (2018) and Sugumar et al. (2017) and Marqués-Lespier JM (2013) also showed that educational interventions play an important role in increasing the knowledge and attitude of staffs of different medical departments in brain death and organ donation processes and it is necessary to implement educational programs continuously to increase knowledge and improve the performance of the staffs (43-46). The results of the study conducted by Aghayan et al. (2009) to evaluate the effect of the lecture-based educational workshop on the nurses' knowledge and attitudes on donation in Tehran (47, 48), showed that the implementation of the educational program had no effect on the attitude of nurses and no relationship was found between the knowledge and attitude, which was not consistent with the result of the present study (49). Its reason can be type of educational program. The mentioned study was conducted in a lecture form for an hour, while clinical scenario and reflective thinking for 8 hours were used in our study (50).

\section{CONCLUSION}

The present study showed that the implementation of educational interventions in the area of brain death and the organ donation has led to an increase in the level of knowledge and attitude of head nurses and clinical supervisors. Therefore, it is recommended that this educational program can be implemented for other medical disciplines.

\section{ACKNOWLEDGEMENT}

This paper was derived from a research project (code 97381) approved by the Fasa University of Medical Sciences. The authors appreciate (acknowledge) Fasa University of Medical Sciences for financial supports of this research.

\section{Conflict of Interest}

There is no conflict of interest to declared.

\section{REFERENCES}

1. Wilson L, Carter A. Organ donation. Br J Hosp Med (Lond). 2018 Jan 2;79(1):8-12. https://doi.org/10.12968/ hmed.2018.79.1.C8 PMid:29315033

2. Srinivasula S, Srilatha A, Doshi D, Reddy BS, Kulkarni S. Influence of health education on knowledge, attitude, and practices toward organ donation among dental students. J Edu Health Promot 2018;7:157.

3. Bharambe VK, Arole VU, Puranam V, Kulkarni PP, Kulkarni PS. Knowledge and attitude toward organ donation among health-care professionals in a rural town in India. Saudi J Kidney Dis Transpl 2018;29:671-9. https://doi.org/ 10.4103/1319-2442.235176

4. Marqués-Lespier JM, Ortiz-Vega NM, Sánchez MC, Sánchez MC, Soto-Avilés OE3, Torres EA. Knowledge of and attitudes toward organ donation: a survey of medical students in Puerto Rico. P R Health Sci J. 2013 Dec;32(4):187-93.

5. Rydzewska M, Drobek NA, Małyszko ME, Zajkowska A, Malyszko J. Opinions and Attitudes of Medical Students About Organ Donation and Transplantation. Transplant Proc. 2018 Sep;50(7):1939-45. https://doi.org/10.1016/ j.transproceed.2018.03.128 PMid:30177084

6. AlShareef SM, Smith RM. Saudi medical students knowledge, attitudes, and beliefs with regard to organ donation and transplantation. Saudi J Kidney Dis Transpl. 2018 Sep-Oct;29(5):1115-27. https://doi.org/10.4103/13192442.243963 PMid:30381508 
7. Lin LM, Lin CC, Lam HD, Chen CL. Increasing the Participation of Intensive Care Unit Nurses to Promote Deceased Donor Organ Donation. Transplant Proc 2010. https://doi.org/10.1016/j.transproceed.2010.03.022 PMid:20430155

8. Hoy H, Alexander S, Frith KH. Effect of transplant education on nurses' attitudes toward organ donation and plans to work with transplant patients. Prog Transplant. 2011;21(4):317-21. https://doi.org/10.7182/prtr.21.4.x5q23 78623281h61 PMid:22548994

9. Masoumian Hoseini ST, Manzari Z, Khaleghi I. ICU Nurses' Knowledge, Attitude, and Practice Towards their Role in the Organ Donation Process from Brain-Dead Patients and Factors Influencing it in Iran. Int J Organ Transplant Med. 2015;6(3):105-13.

10. Salehi S, Kanani T, Abedi H. Iranian nurses' experiences of brain dead donors care in intensive care units: A phenomenological study. Iranian journal of nursing and midwifery research. 2013 Nov;18(6):475-82.

11. Naçar M, Çetinkaya F, Baykan Z, Elmalı F. Knowledge Attitudes and Behaviors About Organ Donation Among First- and Sixth-class Medical Students: A Study From Turkey. Transplant Proc. 2015 Jul-Aug;47(6):1553-9. https://doi.org/10.1016/j.transproceed.2015.02.029 PMid:26293012

12. Khalid F, Khalid AB, Muneeb D, Shabir A, Fayyaz D, Khan M. Level of knowledge and attitude regarding organ donation: a community-based study from Karachi, Pakistan. BMC Res Notes. 2019 May 30;12(1):309. https://doi.org/10.1186/ s13104-019-4345-6 PMid:31146765 PMCid:PMC6543638

13. Poreddi V, Katyayani BV, Gandhi S, Thimmaiah R, Badamath S. Attitudes, knowledge, and willingness to donate organs among Indian nursing students. Saudi J Kidney Dis Transpl. 2016 Nov-Dec;27(6):1129-38. https://doi.org/10.4103/1319-2442.194595 PMid:27900957

14. Huern SY, Yee KC, Rajah JS, Ponniah MP, Sapini MIB. Knowledge, awareness and attitudes on organ donation among undergraduate medical students in Malaysia: An analytical cross sectional study. $\mathrm{Br} \mathrm{J}$ Med Med Res 2016;16:1-14. https://doi.org/10.9734/BJMMR/2016/26208

15. Valiee S, Dehghani Sh, Mohammadi Sh, Dalvand $S$, Khanpour F. Study of knowledge and attitude of nurses in Sanandaj city toward organ donation. Nurs Pract Today. 2019;6(2):74-82. https://doi.org/10.18502/npt.v6i2.912

16. Azmandian J, Poorhoseini S, Shokouhi M, Mirzaei MR. Study of education effect on nurses' knowledge and attitudes about organ donation at the time of brain death. Iran J Crit Care Nurs 2013;6(1):11-20.

17. Lin LM, Lin CC, Chen CL, Lin CC. Effects of an education program on intensive care unit nurses' attitudes and behavioral intentions to advocate deceased donor organ donation. Transplant Proc. 2014 May;46(4):1036-40. https://doi.org/10.1016/j.transproceed.2013.12.039 PMid:24815121

18. Steenaart E, Crutzen R, Candel MJJM, de Vries NK. A webbased education program to encourage organ donation registration among lower-educated adolescents in the Netherlands: study protocol for a cluster randomized controlled trial. Trials. 2018 Oct 1;19(1):532. https://doi.org/10.1186/s13063-018-2927-6 PMid:30285823 PMCid:PMC6167828
19. Srinivasula S, Srilatha A, Doshi D, Reddy BS, Kulkarni S. Influence of health education on knowledge, attitude, and practices toward organ donation among dental students. J Edu Health Promot 2018;7:157.

20. Sugumar JP, Padhyegurjar MS, Padhyegurjar SB. An interventional study on knowledge and attitude regarding organ donation among medical students. Int J Med Sci Public Health 2017;6:402-8. https://doi.org/10.5455/ ijmsph.2017.19082016631

21. Marqués-Lespier JM, Ortiz-Vega NM, Sánchez MC, Sánchez MC, Soto-Avilés OE3, Torres EA. Knowledge of and attitudes toward organ donation: a survey of medical students in Puerto Rico. P R Health Sci J. 2013 Dec; 32(4):187-93.

22. Aghayan HR, Arjmand B, Emami-Razavi SH, Jafarian A, Shabanzadeh AR, Jalali F.et al. Organ donation workshop a survey on nurses' knowledge and attitudes toward organ and tissue donation in Iran. Int J Artif Organs. 2009 Oct;32(10):739-44. https://doi.org/10.1177/0391398809032 01005 PMid:19943235

23. Yadollahi P, Khalajinia Z, Khormaei F. Cultural differences in perception of labor pain without considering to painless technique. Journal of Advanced Pharmacy Education \& Research, 2018;8(S2):9-14.

24. Yadollahi P, Taghizdeh Z, Ebadi A. A comprehensive description of delivery pain using a qualitative approach. Journal of Advanced Pharmacy Education \& Research, 2018;8(S2):59-63.

25. Khorasani Baghini F, Khosravani M, Amiri A. Evaluation of the effect of the provided training in delivery preparation classes on awareness and attitude of pregnant mothers toward delivery type in Razi Hospital of Saravan. Revista Latinoamericana de Hipertension, 2018;13(6):534-7.

26. Khorasani Baghini F, Khosravani M, Amiri A. Evaluation of the effect of the provided training in delivery preparation classes on awareness and attitude of pregnant mothers toward delivery type in Razi Hospital of Saravan, Revista Latinoamericana de Hipertensión. 2018;13(6). Available at: http://saber.ucv.ve/ojs/index.php/rev_lh/article/view/159 49

27. Hashemi SB, Amirfakhraei A, Mosallanezhad M, Amiri A. The effect of education on anxiety and self-efficacy in mothers of 1-3-year-old children under cochlear implant surgery, 2018: a randomized controlled clinical trial, Revista Latinoamericana de Hipertensión. 2019;14(1). Available at: http://saber.ucv.ve/ojs/index.php/rev_lh/article/view/161 70

28. Mahnaz R, Khatereh R, Elahe S, Jamshid E. The relationship between leadership style and time management in senior and middle nursing managers, Revista Latinoamericana de Hipertensión. 2019;14(1). Available at: http://saber.ucv.ve/ ojs/index.php/rev_lh/article/view/16173

29. Khatereh R, Farkhondeh S, Ladan Z, Abbass E, Arash F. Design and Psychometrics of Measurement Tool of Health Needs in Patients with Chronic Back Ache, Revista Latinoamericana de Hipertensión. 2018;13(3). Available at: http://www.revhipertension.com/index_sumario_3_2018. html

30. Rostami K, Zadeh SH, Rakhshan M. Chronic pain: a concept analysis. Electronic Journal of General Medicine. 2019;16(2):em130. https://doi.org/10.29333/ejgm/94098

31. Bazrafcan L, Amini M. Using CRISIS model for designing master in medical education at Shiraz University of Medical Sciences, Medical Teacher. 2019. https://doi.org/ 10.1080/0142159X.2018.1562540 PMid:30736706 
32. Bazrafcan L, Kojuri J, Amini M. Using SPICES educational strategy for undergraduate curricular reform at Shiraz Medical School, Medical Teacher. 2019. https://doi.org/ 10.1080/0142159X.2019.1582759 PMid:30922163

33. Eslami J, Baghini FK, Moazamfard M. The Effect of Music on the Stress Severity among the Staff of Surgery Rooms. International Journal of Pharmaceutical Research. 2019;11(2):838-43. Available at: http://ijpronline.com/ ViewArticleDetail.aspx?ID=7339

34. Rezapour-Nasrabad R. Application of Transitional Care Model in Patients with Chronic Heart Disease: A CaseControlled Intervention Study, Revista Latinoamericana de Hipertensión. 2018;13(3). Available at: http://www. revhipertension.com/index_sumario_3_2018.html

35. Rezapour-Nasrabad R. Transitional care model: managing the experience of hospital at home, Electronic Journal of General Medicine, 2018;15(5):em73. https:/doi.org/ 10.29333/ejgm/93445

36. Gholamrezaei A, Rezapour-Nasrabad R, Ghalenoei M, Nasiri M. Correlation between suicide literacy and stigmatizing attitude of nurses toward patients with suicide attempts, Revista Latinoamericana de Hipertensión. 2019;14(3):3515. Available at: http://saber.ucv.ve/ojs/index.php/rev_lh/ article/view/16760

37. Amirfakhraei A, Hedayati M, Pirmoradi M. Coping Styles with psychological pressures in students of Iran University of medical sciences, International Journal of Pharmaceutical Research, January-March 2019;11(1):5347. https://doi.org/10.31838/ijpr/2019.11.01.071

38. Pirmoradi M, Foroghinejad N, Bedmeshki FA. The relationship between job satisfaction and social support for employees with chronic fatigue. Ann Trop Med Public Health 2017;10:1681-5. https://doi.org/10.4103/ ATMPH.ATMPH_582_17

39. Pirmoradi M, Ghayoomi R, Foroghinejad N, Bedmeshki FA. The relationship between stressful life events with chronic fatigue in employees of Ahvaz water and Sewage Company, Annals of Tropical Medicine and Public Health-Special Issue Apr 2018;13:SX735-18. Available at: http://www. atmph-specialissues.org/

40. Pirmoradi MR, Poya FS, Rad MT, Veisy F, Gheitarani B, Davoodi R, Ghahari S. Comparison of Anxiety, Depression and Stress and Emotional Self-Regulation in Normal and Divorced Women. International Journal of Tropical Medicine, 2016;11:159-64. https://doi.org/10.3923/ ijtmed.2016.159.164

41. Bazrafkan L, Yousefy A, Amini M, Yamani N. The journey of thesis supervisors from novice to expert: a grounded theory study. BMC medical education. 2019 Dec;19(1):1-2. https://doi.org/10.1186/s12909-019-1739-z PMid:31438935 PMCid:PMC6704648
42. Bijani M, Ghodsbin F, Javanmardi Fard S, Shirazi F, Sharif F, Tehranineshat $B$, An evaluation of adherence to ethical codes among nurses and nursing students, J Med Ethics Hist Med. 2017 Jul 5;10:6. Availablea at: https://www.ncbi. nlm.nih.gov/pmc/articles/PMC5746660/

43. Torabizadeh C, Ghodsbin F, Javanmardifard S, Shirazi F, Amirkhani M, Bijani M. The Barriers and Challenges of Applying New Strategies in the Clinical Evaluation of Nursing Students from the Viewpoints of Clinical Teachers, Iran J Nurs Midwifery Res. 2018 Jul-Aug;23(4):305-10. https://doi.org/10.4103/ijnmr.IJNMR_17_17 PMid:30034492 PMCid:PMC6034533

44. Bijani M, Rostami K, Momennasab M, Yektatalab S, Evaluating the Effectiveness of a Continuing Education Program for Prevention of Occupational Exposure to Needle Stick Injuries in Nursing Staff Based on Kirkpatrick's Model, J Natl Med Assoc. 2018 Oct;110(5):459-63. https://doi.org/10.1016/j.jnma.2017.11.002 PMid:30129513

45. Torabizadeh C, Mahnazrakhshan, Zhilafreidooni, Njimehbeygi, Bijani M. Professional Capability in Nursing, International Journal of Pharmaceutical Research, January- March 2019;11(1):556-66. https://doi.org/ 10.31838/ijpr/2019.11.01.075

46. Bijani M, Haghshenas A, Ghasemi A. Evaluation of the Effect of Education Based on Health Belief Model on Self-Therapy and Self-medication in Students at Fasa Medical Sciences Dormitories, International Journal of Pharmaceutical Research, Jan-Mar 2019;11(3). https://doi.org/10.31838/ ijpr/2019.11.01.124

47. Bijani M, Khaleghi AA, Hatami M, Najafi H, Haghshenas A. A study of the consistency between hypertension medications prescribed by general practitioners and 2018 ESC/ESH guidelines for the management of hypertension, Revista Latinoamericana de Hipertensión. 2019;14(1). Available at: http://saber.ucv.ve/ojs/index.php/rev_lh/ article/view/16174

48. Bijani M, Tehranineshat B, Torabizadeh C. Nurses', nursing students', and nursing instructors' perceptions of professional values: A comparative study, Nurs Ethics. 2019 May;26(3):870-83. https://doi.org/10.1177/096973301772 7153 PMid:28905676

49. Bijani M, Ghasemi A, Karimi S, Freidooni Z, Beygi N. The Role of Educational Intervention Based on the Health Belief Model in Colorectal Cancer Screening of Teachers in Fasa. Journal of Computational and Theoretical Nanoscience. 2019;16(7):2954-2958(5). https://doi.org/10.1166/jctn.2019 .8201

50. Bijani M, Rostami K, Ghasemi A, Emami M, Fereidouni Z. Investigation of diabetes prevention behaviors among teachers of different level of education based on Pender model in selected educational centers in southwestern Iran, 2019. Revista Latinoamericana de Hipertensión. 2019;14 (4):290-4. 